\title{
Penambahan Essens Buah untuk Meningkatkan Keefektifan Metil Eugenol dalam Menarik Bactrocera spp. Drew \& Hancock
}

\author{
Agus Susanto ${ }^{1 *}$, Ceppy Nasahi ${ }^{1}$, Yuri Khansa Rumaisha², Wayan Murdita ${ }^{3}$, dan \\ Tri Murniningtyas Puji Lestari ${ }^{3}$ \\ ${ }^{1}$ Departemen Hama dan Penyakit Tumbuhan, Fakultas Pertanian, Universitas Padjadjaran \\ Jl. Raya Bandung-Sumedang KM 21 Jatinangor, Jawa Barat 45363 \\ ${ }^{2}$ Program Studi Agroteknologi, Fakultas Pertanian, Universitas Padjadjaran \\ Jl. Raya Bandung-Sumedang KM 21 Jatinangor, Jawa Barat 45363 \\ ${ }^{3}$ Balai Besar Peramalan Organisme Pengganggu Tanaman \\ Jl. Raya Kaliasin Tromol Pos 1 Jatisari, Karawang, Jawa Barat 41374 \\ *Alamat korespondensi: a.susanto@unpad.ac.id
}

\section{ABSTRACT \\ Fruit essence addition to increase the effectiveness of methyl eugenol in attracting Bactrocera spp. Drew \& hancock}

Fruit fly (Bactrocera carambolae) is a very harmful pest of horticulture commodities. The purposes of this research were to find fruit essences which were able to enhance the attractiveness of methyl eugenol to fruit flies, to determine the effect of the mixing of methyl eugenol with guava fruit essences towards the catchment of the fruit flies in guava plantation, and to find the essenses consentration which were able to catch high number of fruit flies. The in vitro experiment was held in Vapor Heat Treatment Laboratory, Pests and Deseases Forecasting Institute, Jatisari, West Java from Februari to June 2015 and in guava plantation at the village of Leuwiseeng, Panyingkiran District, Majalengka from December 2015 until April 2016. The results showed that methyl eugenol added by star fruit and orange essences had an effect on increasing the catch of female fruit flies, but not for male fruit flies. The highest treatment in attracting female fruit flies was the addition of star fruit essences which was able to attract $37 \%$ of the total population. The highest treatment in attracting male fruit flies (10\% of the total population) was treatment of $0.2 \mathrm{ml}$ of methyl eugenol. Mixture of methyl eugenol and guava fruit essences can attract male fruit flies higher than single use of methyl eugenol and single use of guava essences. It catched highest number of male fruit flies at 15,145. However, the mixing of methyl eugenol and guava essences did not affect the number of catches of female fruit flies. The most dominant fruit fly species identified in guava plantations in Leuwiseeng Village, Majalengka, were $B$. dorsalis $64 \%$ and $B$. carambolae $36 \%$.

Keyword: Essence, Bactrocera carambolae, Methyl eugenol

\begin{abstract}
ABSTRAK
Lalat buah (Bactrocera carambolae) merupakan hama yang sangat merugikan pada komoditas hortikultura. Penelitian ini bertujuan untuk mendapatkan jenis essens buah yang ditambahkan pada metil eugenol yang tertinggi dalam menarik lalat buah, untuk mengetahui pengaruh penambahan essens jambu pada metil eugenol terhadap jumlah tangkapan lalat buah pada pertanaman jambu biji, dan berapa konsentrasi essens yang menghasilkan jumlah tangkapan lalat buah paling banyak. Penelitian secara in vitro dilakukan di Laboratorium Vapor Heat Treatment, Balai Peramalan Organisme Pengganggu Tumbuhan, Jatisari, Jawa Barat dari bulan Februari 2015 hingga Juni 2015 dan di kebun jambu biji Desa Leuwiseeng, Kecamatan Panyingkiran, Kabupaten Majalengka sejak bulan November 2015 sampai dengan Maret 2016. Hasil penelitian menunjukan bahwa metil eugenol yang ditambah essens belimbing dan jeruk berpengaruh dalam meningkatkan
\end{abstract}


hasil tangkapan lalat buah betina, tetapi tidak untuk lalat buah jantan. Perlakuan tertinggi dalam menarik lalat buah betina yaitu sebesar $37 \%$ dari total populasi ditemukan pada perlakuan penambahan essens belimbing. Sementara perlakuan $0,2 \mathrm{ml}$ metil eugenol menarik sebanyak $10 \%$ dari total populasi. Pencampuran metil eugenol dan esens buah jambu mampu menarik lalat buah jantan lebih tinggi dibandingkan penggunaan tunggal metil eugenol dan penggunaan tunggal esens jambu. Pencampuran metil eugenol 0,2 $\mathrm{ml}$ + esens buah jambu 0,8 $\mathrm{ml}$ menunjukkan hasil jumlah tangkapan tertinggi lalat buah jantan sebanyak 15.145 ekor. Namun, pencampuran metil eugenol dan esens jambu tidak mempengaruhi jumlah tangkapan lalat buah betina. Spesies lalat buah yang paling dominan hasil identifikasi pada pertanaman jambu biji di Desa Leuwiseeng, Majalengka, adalah B. dorsalis $64 \%$ dan B. carambolae $36 \%$.

Kata kunci : Essens, Bactrocera carambolae, Metil eugenol

\section{PENDAHULUAN}

Lalat buah (Bactrocera spp.) merupakan hama yang sangat merugikan pada komoditas hortikultura. Berdasarkan Peraturan Menteri Pertanian No 358 Tahun 2005, lalat buah (Familia Tephritidae) dikenal sebagai hama utama (major pest) pada banyak jenis tanaman horikultura yang dapat menurunkan produktivitas buah-buahan dan sayuran buah di dalam negeri. Lebih dari seratus jenis tanaman hortikultura diduga menjadi sasaran serangan lalat buah. Pada populasi yang tinggi, intensitas serangannya dapat mencapai $100 \%$ (Nasution \& Kuswadi, 2012).

Serangan lalat buah dapat mengakibatkan kerusakan hasil secara kualitatif dan kuantitatif. Secara kualitatif, timbulnya kerusakan tertentu akibat adanya penetrasi dan infestasi telur lalat buah betina. Hal tersebut akan memicu terjadinya gangguan fisiologis, seperti perubahan warna dan gangguan perkembangan buah (Sati, 2003 \& Heriza dkk., 2013). Secara kuantitatif, kerusakan dapat mengakibatkan penurunan hasil panen (Heriza dkk., 2013). Penurunan hasil panen akibat serangan lalat buah berkisar 50-75\% (Asman, 2004).

Lalat buah termasuk hama yang sulit untuk dikendalikan. Pengendalian lalat buah dengan cara kimia yang mengunakan insektisida tergolong sulit dan berbahaya sebab dapat meninggalkan residu pada buah atau jaringan buah. Hal ini tentunya sangat berbahaya bagi mahluk hidup terutama manusia dan hewan serta lingkungan (Kardinan, 2003). Oleh sebab itu perlu alternatif pengendalian yang tepat dengan biaya rendah dan keefektifannya tinggi serta aman bagi lingkungan. Salah satu upaya pengendalian lalat buah yang telah berhasil dan sukses dilakukan adalah pengendalian dengan teknik pengunaan perangkap atraktan. Atraktan adalah senyawa kimia yang dapat memikat lalat buah yang nantinya akan masuk ke dalam perangkap (Lengkong dkk., 2011). Salah satu atraktan yaitu metil eugenol yang merupakan paraferomon untuk menarik serangga jantan Bactrocera dorsalis (Epsky \& Heath, 1998).

Metil eugenoladalah senyawa kimia yang bersifat atraktan atau sebagai penarik serangga terutama terhadap lalat buah jantan tertentu. Atraktan ini tidak meninggalkan residu pada buah dan mudah diaplikasikan pada lahan yang luas, karena bersifat volatil(mudah menguap), daya jangkaunya atau radiusnya cukup jauh, mencapai ratusan meter bahkan ribuan meter bergantung pada arah angin. Daya tangkap atraktan bervariasi bergantung pada lokasi, cuaca, komoditas dan keadaan buah di lapangan (Balai Penelitian Pertanian Lahan Rawa, 2013).

Penggunaan perangkap menggunakan metil eugenol masih memiliki kelemahan, yaitu hanya dapat menarik lalat buah jantan saja. Salah satu alternatif teknik pengendalian hama lalat buah yang lebih efektif yaitu dapat dilakukan penambahan aroma pada perangkap lalat buah. Aroma buah dilaporkan dapat menarik lalat buah betina dewasa (Prokopy et al., 1991). Hal ini didukung oleh pernyataan Jang \& Light (1996) bahwa aroma buah dari tanaman inang dapat meningkatkan oviposisi (penetasan telur) pada lalat buah betina sehingga dengan ditambahkannya aroma dapat meningkatkan kinerja perangkap yaitu dapat menarik lalat buah betina. Terdapat empat jenis essens buah yang digunakan dalam pelaksanaan percobaan yaitu essens belimbing, jambu, mangga dan jeruk. Penggunaan jenis-jenis essens buah tersebut dilakukan karena keempat jenis buah banyak diserang oleh lalat buah (Sauers-Muller, 2005; Novriarche, 2012).

$\begin{array}{rlr}\text { Penggunaan } & \text { perangkap atraktan metil } \\ \text { eugenol dengan penambahan essens } & \text { buah }\end{array}$


diharapkan tidak hanya dapat menarik lalat buah jantan, tetapi juga dapat menarik lalat buah betina. Dengan demikian perlu dilakukan penelitian mengenai penambahan essens buah untuk meningkatkan kinerja metil eugenol dalam menarik lalat buah.

\section{BAHAN DAN METODE}

Penelitian dilakukan di Laboratorium Vapour Heat Treatment (VHT), Balai Besar Peramalan Organisme Pengganggu Tumbuhan (BBPOPT), Jatisari, Karawang, Jawa Barat dengan ketinggian tempat 35 meter di atas permukaan laut. Penelitian dilakukan dimulai dari bulan Februari 2015 sampai Juni 2015 dan di kebun jambu Desa Leuwiseeng, Kecamatan Panyingkiran, Kabupaten Majalengka pada ketinggian tempat berkisar $100 \mathrm{~m}$ di atas permukaan laut (dpl). Penelitian dimulai sejak bulan November 2015 sampai dengan Maret 2016.

Penelitian di laboratorium menggunakan Rancangan Acak Kelompok (RAK) dengan 5 perlakuan dan 5 ulangan untuk di laboratorium yang terdiri dari persiapan alat dan bahan, pengujian penambahan essens buah terhadap keefektifan metil eugenol dalam menarik lalat buah (B. carambolae) jantan dan betina.

\section{Persiapan serangga uji}

Perbanyakan lalat buah $B$. carambolae dilakukan di Laboratorium VHT BBPOPT, Jatisari, Jawa Barat. Pertama yang dilakukan adalah peneluran (egging) dalam egging device (Gambar 1a). Setelah dua jam telur dipanen dengan menyemprotkan air ke dalam egging device. Telur diambil dan dipindahkan ke atas saringan halus menggunakan pipet dengan jumlah telur sebanyak 1 ml. Telur yang telah diambil dipindahkan ke atas tisu. Tisu tersebut diletakkan diatas kotak pakan larva kemudian dimasukkan ke dalam biotron dengan suhu $28^{\circ} \mathrm{C}$ dan kelembaban $65 \%$ (Gambar 1b).

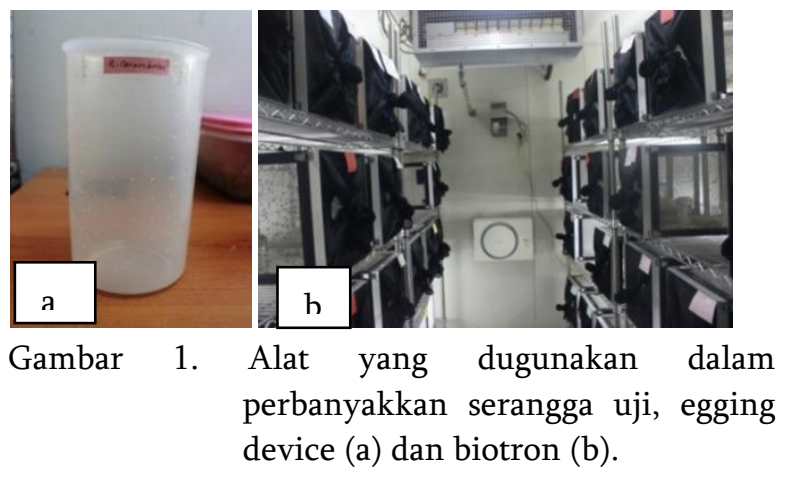

Setelah dimasukan ke dalam biotron (Gambar 1b), kotak pakan larva dimasukan ke dalam kotak besi berukuran $30 \mathrm{~cm}$ x $30 \mathrm{~cm}$. Kotak tersebut sebelumnya diisi dengan serbuk gergaji yang telah disterilisasi dan dilembabkan yang berfungsi sebagai media untuk perkembangan pupa. Pada hari kelima setelah penyimpanan, pupa diayak untuk memisahkan antara serbuk gergaji dan pupa, kemudian pupa dipindahkan ke dalam kotak berukuran $45 \mathrm{~cm}$ x $30 \mathrm{~cm}$ x $30 \mathrm{~cm}$ sebagai tempat perkembangan imago. Hal tersebut dilakukan dengan tujuan untuk memperoleh serangga uji yang seragam.

\section{Penambahan essens buah pada metil eugenol dalam menarik lalat buah $B$. carambolae}

Pengaruh penambahan essens buah pada metil eugenol dalam menarik lalat buah diuji secara mandiri dengan menggunakan tabung Y (Gambar 2). Pengujian ini bertujuan untuk membandingkan antara perlakuan penambahan essens buah pada metil eugenol dalam menangkap lalat buah dengan perlakuan kontrol tanpa metil eugenol dan essens buah. Metil eugenol ditambah essens buah yang diuji diteteskan pada kapas. Kapas tersebut digantungkan pada tutup stoples (B) dan kapas tanpa diberi metil eugenol dan essens buah digantungkan pada tutup stoples (C). Sebanyak 10 pasang $B$. carambolae dari kurungan rearing dipindahkan ke dalam stoples (A) dengan menggunakan tabung reaksi. Setelah itu dilakukan penghitungan populasi B. carambolae. Nilai ketertarikan lalat buah terhadap senyawa uji dalam bentuk persen dan dihitung menggunakan rumus di bawah ini.

Nilai ketertarikan lalat buah

$$
=\frac{\text { jumlah lalat buah yang tertarik }}{\text { jumlah total lalat buah yang diuji }} \times 100 \%
$$

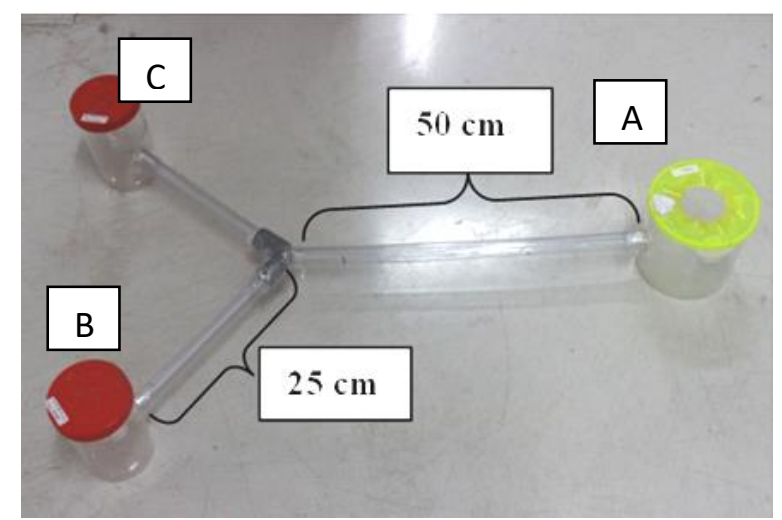

Gambar 2. Tabung Y yang digunakan untuk menguji ketertarikan lalat buah terhadap penambahan essens buah pada metil eugenol. 
Penambahan essens buah terhadap peningkatan keefektifan metil eugenol dalam menarik $B$. carambolae

Untuk mengetahui essens buah yang paling baik dalam meningkatkan keefektifan metil eugenol dilakukan pengujian menggunakan olfaktometer (Gambar 3). Terdapat empat jenis essens buah yang digunakan dalam pelaksanaan percobaan yaitu essens belimbing, jambu, mangga, dan jeruk. Metil eugenol $0,2 \mathrm{ml})$ dan essens buah $(0,2 \mathrm{ml})$ yang diuji diteteskan pada kapas, yang kemudian digantungkan pada tutup stoples pada kelima tangan olfaktometer. Sebanyak 20 pasang B. carambolae dengan kisaran umur 14-22 hari setelah kemunculan imago, dimasukkan ke dalam pusat olfaktometer dengan menggunakan tabung reaksi. Setelah itu dilakukan penghitungan populasi $B$. carambolae pada setiap perlakuan. Nilai ketertarikan lalat buah terhadap senyawa uji dalam bentuk persen dan dihitung menggunakan rumus seperti di atas.

\section{Pengamatan}

Pengamatan dilakukan selama 24 jam dengan interval waktu pengamatan 30', 1, 6, 12 dan 24 jam setelah aplikasi (JSA). Pengamatan terdiri dari jumlah tangkapan lalat buah jantan dan jumlah tangkapan lalat buah betina, pengamatan perilaku lalat buah selama 1 jam setelah aplikasi perlakuan. Hal tersebut dilakukan untuk mengetahui bagaimana respon lalat buah terhadap masing- masing perlakuan saat tertarik untuk makan ataupun melakukan perkawinan.

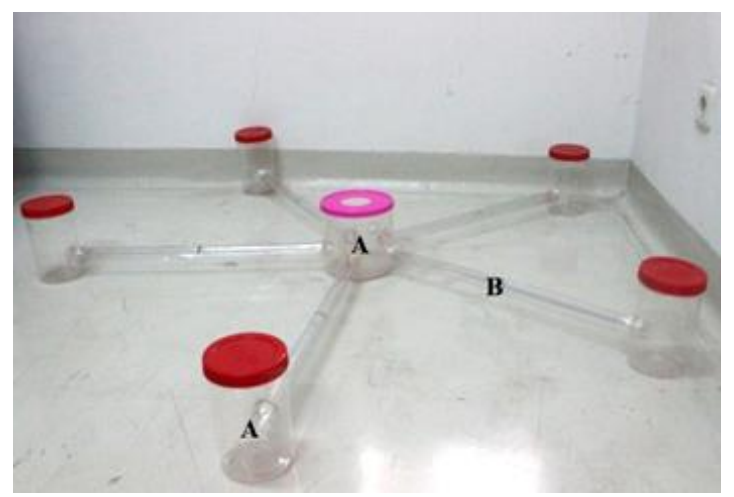

Gambar 3. Olfaktometer. $\mathrm{A}=$ toples, $\mathrm{B}=$ tabung mika (Susanto, 2010).

\section{HASIL DAN PEMBAHASAN}

Penambahan essens buah pada metil eugenol dalam menarik lalat buah $B$. carambolae

Hasil analisis uji Independent-Samples T Test menunjukkan bahwa perlakuan penambahan essens belimbing dan jambu pada metil eugenol berpengaruh nyata dalam menarik lalat buah betina B. carambolae (Gambar 4). Sementara perlakuan dengan penambahan essens jeruk dan mangga tidak menunjukkan adanya pengaruh yang nyata dalam menarik baik lalat buah B. carambolae jantan (Gambar 4) maupun betina (Gambar 5).

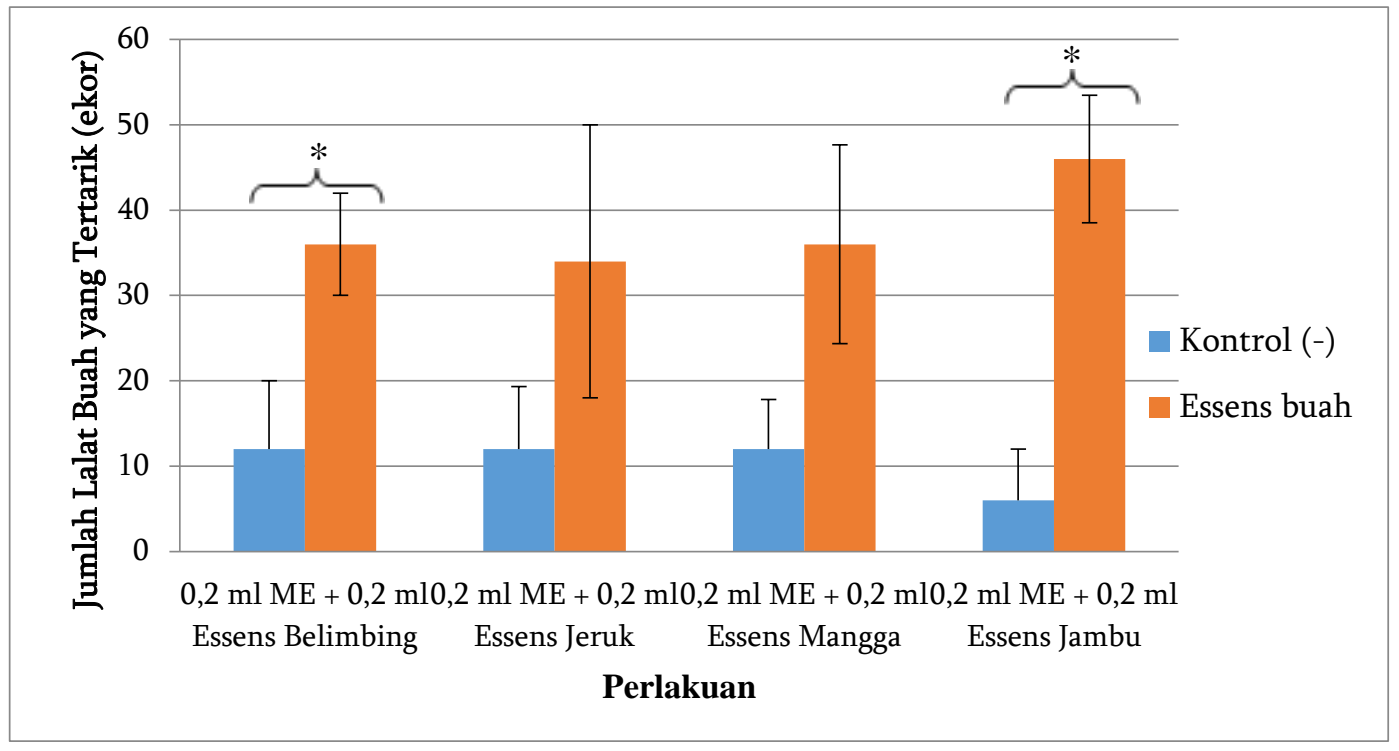

Gambar 4. Persentase ketertarikan lalat buah jantan B. carambolae terhadap perlakuan pada 24 JSA. Tanda bintang $\left({ }^{*}\right)$ menunjukan perlakuan berpengaruh nyata berdasarkan uji Independent-Sample $\mathrm{T}$ Test pada taraf nyata 5\%. Error bar $=($ mean \pm sd $)$. 
Penambahan essens belimbing dan jambu menunjukkan hasil yang lebih baik dalam menarik lalat buah jantan dan betina $B$. carambolae dibandingkan dengan kontrol tanpa metil eugenol dan essens buah. Hal ini sesuai dengan penelitian Sauers-Muller (2005) yang menyebutkan bahwa belimbing merupakan inang utama lalat buah $B$. carambolae, dengan $32 \%$ dari sampel ditemukan lalat buah B. carambolae di lapangan. Selain itu, lalat buah $B$. carambolae juga banyak ditemui pada tanaman apel dan jambu sebanyak 20,45\%. Kombinasi antara ekstrak belimbing dan metil eugenol merupakan atraktan terbaik terhadap aktivitas perilaku makan lalat buah Bactrocera dorsalis (Wati dkk., 2013).

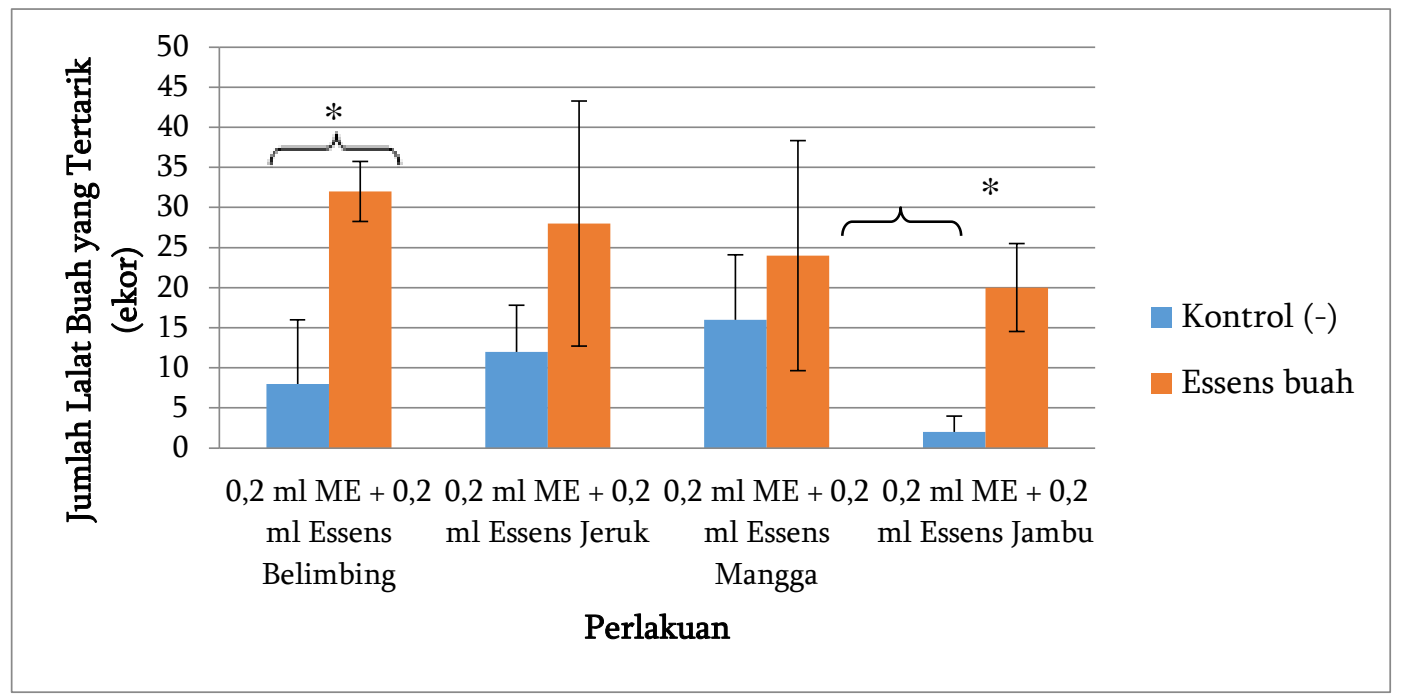

Gambar 5. Persentase ketertarikan lalat buah betina B. carambolae terhadap perlakuan pada 24 JSA. Tanda bintang $\left(^{*}\right)$ menunjukan perlakuan berpengaruh nyata berdasarkan uji Independent-Sample T Test pada taraf nyata 5\%. Error bar $=($ mean $\pm s d)$.

Persentase ketertarikan lalat buah betina $B$. carambolae pada perlakuan $0,2 \mathrm{ml}$ metil eugenol + $0,2 \mathrm{ml}$ essens belimbing lebih tinggi dibandingkan kontrol tanpa metil eugenol dan essens buah yaitu sebanyak 32\% dan perlakuan 0,2 $\mathrm{ml}$ metil eugenol + $0,2 \mathrm{ml}$ essens jambu lebih tinggi dibandingkan kontrol yaitu sebanyak 20\%. Penambahan essens belimbing dan jambu menunjukkan hasil yang lebih baik dibandingkan dengan kontrol dalam menarik lalat buah betina $B$. carambolae. Penambahan essens jeruk dan mangga menunjukkan tidak menunjukkan perbedaan yang nyata dengan kontrol dalam menarik lalat buah jantan.

Lalat buah dewasa menggunakan rangsangan visual dan penciuman untuk kemampuan mencari inang (Sunarno, 2011). Penarik kimia sintetik buatan yang disebut paraferomon merupakan atraktan yang dapat menyebabkan respon yang mirip dengan feromon aslinya (Epsky \& Heath, 1998). Metil eugenol adalah paraferomon yang dapat menarik lalat buah jantan dari Bactrocera dorsalis (Hendel). Lalat buah betina menemukan inangnya untuk meletakkan telur. Aroma buah inang dapat menjadi rangsangan lalat buah betina untuk menemukan inang (Aluja \& Prokopy, 1993).

$$
\text { Penelitian Hasyim dkk. }
$$
menunjukkan lalat buah lebih banyak terperangkap, pada perangkap warna kuning (39 ekor), kemudian diikuti oleh perangkap warna merah, hijau, oranye dan transparan. Hal ini sesuai dengan hasil pengamatan yang telah dilakukan bahwa lalat buah tertarik pada perlakuan kontrol, yang diduga karena tutup stoples pada kontrol yang berwarna merah.

\section{Pengujian penambahan essens buah terhadap keefektifan metil eugenol dalam menarik lalat buah jantan}

Hasil analisis sidik ragam menggunakan uji F menunjukkan bahwa penambahan essens terhadap keefektifan metil eugenol memberikan pengaruh nyata terhadap variabel pengamatan persentase ketertarikan lalat buah jantan $B$. carambolae pada pengamatan 30 menit dan 1 Jam Setelah Aplikasi (JSA) (Tabel 1). Penambahan essens terhadap keefektifan metil eugenol tidak berpengaruh nyata dalam menarik lalat buah jantan $B$. carambolae selama pengamatan 6 hingga 24 JSA. Perlakuan 0,2 
$\mathrm{ml} \mathrm{ME} \mathrm{+} \mathrm{0,2} \mathrm{ml} \mathrm{essens} \mathrm{mangga} \mathrm{(D)} \mathrm{dan} \mathrm{0,2} \mathrm{metil}$ eugenol (A) memiliki nilai persentase ketertarikan lalat buah jantan $B$. carambolae yang lebih tinggi dibandingkan dengan perlakuan lainnya pada pengamatan 30 menit dan 1 JSA. Berdasarkan data tersebut, dapat diindikasikan bahwa menggunakan metil eugenol saja mampu menarik lalat buah jantan B. carambolae. Hal ini disebabkan persentase lalat buah jantan yang tertangkap dalam penggunaan metil eugenol memiliki persentase ketertarikan yang sama baiknya dengan penggunaan metil eugenol yang ditambahkan dengan essens buah.

Tabel 1. Pengaruh penambahan essens buah terhadap metil eugenol dalam menarik lalat buah jantan $B$. carambolae (\%) ( $\mathrm{N}=20$ ekor per perlakuan)

\begin{tabular}{lccccc}
\hline \multirow{2}{*}{ Perlakuan } & \multicolumn{5}{c}{ Persentase lalat buah jantan yang tertarik pada JSA (\%) } \\
\cline { 2 - 6 } & 0,5 & 1 & 6 & 12 & 24 \\
\hline $\mathrm{A}=0,2 \mathrm{ml} \mathrm{ME}$ & $9 \mathrm{ab}$ & $12 \mathrm{ab}$ & $11 \mathrm{a}$ & $11 \mathrm{a}$ & $10 \mathrm{a}$ \\
$\mathrm{B}=0,2 \mathrm{ml} \mathrm{ME}+0,2 \mathrm{ml}$ Essens Belimbing & $0 \mathrm{~b}$ & $1 \mathrm{c}$ & $6 \mathrm{a}$ & $18 \mathrm{a}$ & $20 \mathrm{a}$ \\
$\mathrm{C}=0,2 \mathrm{ml} \mathrm{ME}+0,2 \mathrm{ml}$ Essens Jeruk & $1 \mathrm{~b}$ & $2 \mathrm{bc}$ & $11 \mathrm{a}$ & $23 \mathrm{a}$ & $42 \mathrm{a}$ \\
$\mathrm{D}=0,2 \mathrm{ml} \mathrm{ME}+0,2 \mathrm{ml}$ Essens Mangga & $17 \mathrm{a}$ & $19 \mathrm{a}$ & $28 \mathrm{a}$ & $25 \mathrm{a}$ & $25 \mathrm{a}$ \\
$\mathrm{E}=0,2 \mathrm{ml} \mathrm{ME}+0,2 \mathrm{ml}$ Essens Jambu & $2 \mathrm{~b}$ & $2 \mathrm{bc}$ & $2 \mathrm{a}$ & $12 \mathrm{a}$ & $13 \mathrm{a}$ \\
\hline
\end{tabular}

Keterangan : $\quad$ - JSA= Jam Setelah Aplikasi, ME= Metil Eugenol

- Angka yang diikuti oleh huruf yang berbeda dalam satu kolom menunjukan perbedaan yang nyata berdasarkan uji jarak berganda Duncan pada taraf nyata 5\%

Pengujian penambahan essens buah terhadap keefektifan metil eugenol dalam menarik lalat buah betina

Hasil analisis sidik ragam menggunakan uji F menunjukkan bahwa penambahan essens terhadap keefektifan metil eugenol memberikan pengaruh nyata terhadap variabel pengamatan persentase ketertarikan lalat buah betina $B$. carambolae pada pengamatan 6-24 JSA (Tabel 2). Dapat dilihat bahwa bahwa perlakuan 0,2 $\mathrm{ml} \mathrm{ME}+0,2 \mathrm{ml}$ essens belimbing (B) dan 0,2 $\mathrm{ml} \mathrm{ME} \mathrm{+} \mathrm{0,2} \mathrm{ml}$ essens jambu (C) memiliki pengaruh yang nyata dibandingkan perlakuan $0,2 \mathrm{ml}$ metil eugenol (A) pada pengamatan 6-24 JSA.

Tabel 2. Pengaruh penambahan essens buah terhadap keefektifan metil eugenol dalam menarik lalat buah betina $B$. carambolae (\%) $(\mathrm{N}=20$ ekor per perlakuan)

\begin{tabular}{lccccc}
\hline \multirow{2}{*}{ Perlakuan } & \multicolumn{5}{c}{ Persentase lalat buah betina yang tertarik (\%) pada JSA (\%) } \\
\cline { 2 - 6 } & 30 & 1 & 6 & 12 & 24 \\
\hline $\mathrm{A}=0,2 \mathrm{ml} \mathrm{ME}$ & $1 \mathrm{a}$ & $1 \mathrm{a}$ & $2 \mathrm{~b}$ & $2 \mathrm{c}$ & $2 \mathrm{c}$ \\
$\mathrm{B}=0,2 \mathrm{ml} \mathrm{ME}+0,2 \mathrm{ml}$ Essens Belimbing & $1 \mathrm{a}$ & $4 \mathrm{a}$ & $32 \mathrm{a}$ & $37 \mathrm{a}$ & $37 \mathrm{a}$ \\
$\mathrm{C}=0,2 \mathrm{ml} \mathrm{ME}+0,2 \mathrm{ml}$ Essens Jeruk & $1 \mathrm{a}$ & $1 \mathrm{a}$ & $16 \mathrm{ab}$ & $17 \mathrm{abc}$ & $17 \mathrm{abc}$ \\
$\mathrm{D}=0,2 \mathrm{ml} \mathrm{ME}+0,2 \mathrm{ml}$ Essens Mangga & $0 \mathrm{a}$ & $0 \mathrm{a}$ & $3 \mathrm{~b}$ & $5 \mathrm{bc}$ & $5 \mathrm{bc}$ \\
$\mathrm{E}=0,2 \mathrm{ml} \mathrm{ME}+0,2 \mathrm{ml}$ Essens Jambu & $0 \mathrm{a}$ & $3 \mathrm{a}$ & $19 \mathrm{ab}$ & $29 \mathrm{ab}$ & $29 \mathrm{ab}$ \\
\hline Keterangan : & - JSA= Jam Setelah Aplikasi, ME= Metil Eugenol & & \\
& Angka yang diikuti oleh huruf yang berbeda dalam satu kolom menunjukan perbedaan yang nyata \\
& berdasarkan uji jarak berganda Duncan pada taraf nyata 5\%
\end{tabular}

Penambahan essens buah dapat atau aroma buah inang (alami, sintetik, cair atau meningkatkan ketertarikan lalat buah, hal ini kering). Fein et al. (1982) menyatakan Rhagoletis terbukti dengan tertariknya lalat buah betina selama pengamatan. Pengaruh yang ditimbulkan dari penggunaan essens buah ini adalah kemampuan dalam mengacaukan perilaku lalat buah betina dalam mencari inang untuk bertelur. Lalat buah betina mempelajari aroma buah dalam mencari inang untuk oviposisi (Robacker \& Fraser, 2005). Epsky \& Heath (1998) mengungkapkan atraktan untuk lalat buah betina didasarkan pada makanan pomonella betina dewasa tertarik pada aroma apel di lapangan dan senyawa volatil sintetik yang berasal dari apel di laboratorium.

Lalat buah mengenali dan tertarik untuk mendekati buah karena adanya senyawa ester dan terpena yang dikeluarkan dari buah, kemudian ditangkap oleh reseptor lalat buah (Jang \& Light, 1996). Hal ini serupa dengan mekanisme ketertarikan lalat buah terhadap essens buah. Zhang 
et al. (1999) mengungkapkan dari hasil penelitian di laboratorium bioassay, bahwa lalat buah betina $R$. pomonella dapat tertarik oleh campuran lima komponen ester dari aroma apel yaitu butil butanoat (10\%), propol hexanoat (4\%), butil hexanoat (37\%), heksil butanoat (44\%), dan pentil hexanoat (5\%).

Penambahan 0,2 $\mathrm{ml}$ essens buah belimbing dan 0,2 $\mathrm{ml}$ essens buah jeruk ditambah 0,2 $\mathrm{ml}$ metil eugenol menunjukkan hasil yang lebih baik dalam menarik lalat buah betina $B$. carambolae. Hal itu terjadi karena belimbing merupakan inang utama $B$. carambolae (Siwi dkk., 2006). Drew \& Hancock (1994) menyatakan Inang utama $B$. carambolae di Suriname adalah belimbing (Averrhoa carambola) dan jambu (Syzygium samarangense). Pendapat tersebut didukung oleh Szentesi et al. (2011) yang menjelaskan ekstrak tanaman inang utama dapat digunakan untuk menarik lalat buah. Ekstrak tanaman inang ini berfungsi sebagai rangsangan kimia untuk mengenali tempat oviposisi.

Penelitian Himawan dkk. menunjukkan bahwa lalat buah betina B. carambolae lebih banyak tertarik untuk bertelur pada tempat peneluran dengan aroma buah jambu biji (16.437 butir) dan diikuti pada tempat peneluran dengan aroma buah jeruk (12.082 butir), serta belimbing (8.516 butir). Hasil uji lapangan yang telah dilakuakan Cornelius et al. (2000) menunjukan bahwa perangkap McPhail yang beraroma jeruk memiliki jumlah tangkapan yang tinggi. Aroma yang tepat dapat meningkatkan ketertarikan lalat buah. Hal tersebut sesuai dengan penelitian Vargas et al. (1997) menyatakan lalat buah Mediterania betina, $C$. capitata (Wiedemann) pada perangkap yang diberi ekstrak kopi, lebih banyak tertangkap dibandingkan dengan perangkap yang diberi air dan trimedlure.

\section{Perilaku lalat buah \\ Perilaku makan}

Konsep dari mencari makan dapat digunakan untuk menentukan bagaimana lalat buah mencari makan dan mencari tempat untuk meletakkan telur (Prokopy \& Roitberg, 1984). Ketertarikan suatu serangga terhadap suatu objek didasari oleh isyarat-isyarat. Sunarno (2011) menyatakan salah satu isyarat yang digunakan serangga adalah isyarat kimia (chemical cues) untuk menemukan inang. Kesesuaian isyarat kimia ini akan menyebabkan serangga tertarik untuk menemukan suatu objek tertentu.

Pengamatan perilaku makan pada lalat buah jantan dan lalat buah betina memiki respon yang sama saat mendekati atraktan, yaitu mendekati senyawa atraktan secara perlahan sambil menjulurkan alat mulutnya. Saat mencapai ujung olfaktometer, lalat buah jantan dan betina langsung mendekati kapas yang diberi perlakuan. Hal ini sesuai dengan Boror et al. (2001) yang menyatakan bagian mulut merupakan alat pengecap yang berhubungan dengan sel-sel sensorik lalat buah. Alat mulut tersebut menyerupai alat penyedot debu, berupa suatu saluran yang bagian ujungnya melebar dan bekerja dengan menjilat.

\section{Perilaku kawin}

Saat mendekati ujung olfaktometer, lalat buah akan menjulurkan mulutnya untuk mendeteksi keberadaan metil eugenol. Lalat buah jantan yang telah mengkonsumsi metil eugenol memiliki potensi keberhasilan kawin yang lebih baik dibandingkan dengan yang tidak mengkonsumsi metil eugenol. Hal tersebut terjadi karena lalat buah betina lebih menunjukkan ketertarikan pada feromon yang dihasilkan oleh lalat buah jantan yang menkonsumsi metil eugenol (Shelly, 2010).

Wati dkk. (2013) menyatakan bahwa di dalam tubuh lalat buah jantan, metil eugenol diproses menjadi zat pemikat yang akan berguna dalam proses perkawinan. Dalam proses perkawinan tersebut, lalat buah betina akan memilih lalat buah jantan yang telah mengkonsumsi metil eugenol karena lalat buah jantan tersebut mampu mengeluarkan aroma yang berfungsi sebagai feromon seks (daya pikat seksual).

Pengamatan perilaku kawin pada lalat buah B. carambolae dilakukan pada pagi hari selama 1 jam setelah aplikasi, namun di setiap perlakuan tidak ditemukannya lalat buah yang melakukan perkawinan. Hal tersebut terjadi karena lalat buah biasanya melakukan perkawinan pada sore hari yaitu sekitar pukul 17.10 - 18.45 (Dumalang \& Lengkong, 2011).

Pagi hari merupakan waktu yang sering digunakan lalat buah jantan dalam mengunjungi dan mengkonsumsi metil eugenol, namun tidak jarang ditemui aktivitas tersebut pada sore hari karena lalat buah betina tertarik pada waktu tersebut (Shelly, 2010). Hal tersebut didukung oleh pendapat Raghu \& Clarke (2003) yang menyatakan lalat buah jantan kembali ke tempat metil eugenol untuk bertemu lalat buah betina, sehingga dapat melakuakan perkawinan. Berdasarkan uraian tersebut maka metil eugenol merupakan stimulus untuk pertemuan antara lalat buah jantan dan lalat buah betina. 


\section{SIMPULAN}

Berdasarkan penelitian pengaruh penambahan essens terhadap keefektifan metil eugenol dalam meningkatkan tangkapan lalat buah di laboratorium dan di pertanaman jambu dapat ditarik kesimpulan sebagai berikut.

1. Penambahan essens belimbing, dan jambu berpengaruh dalam meningkatkan hasil tangkapan lalat buah betina,

2. Perlakuan tertinggi dalam menarik lalat buah jantan yaitu perlakuan $0,2 \mathrm{ml}$ metil eugenol dengan persentase ketertarikan 10\%, sementara untuk lalat buah betina yaitu pada perlakuan penambahan essens belimbing dengan persentase ketertarikan 37\%.

\section{DAFTAR PUSTAKA}

Aluja, M and RJ Prokopy. 1993. Host odor and visual stimulus interaction during intratree host finding behavior of Rhagoletis pomonella flies. Journal of Chemical Ecology 19 (11) : 2671-2696.

Asman, A. 2004. Daun Wangi Si Pemikat Serangga. Tersedia http://www.agriculturesnetwork.org/magaz ines/indonesia/6-keanekaragaman-hayatipotensi-yang-tersembunyi/daun-wangi-sipemikat-serangga-kacang-

pintoi/at_download/article_pdf (diakses tanggal 21 Januari 2015).

Balai Penelitian Pertanian Lahan Rawa (Balittra). 2013. Metil Eugenol Sebagai Perangkap Lalat Buah. Tersedia http://balittra.litbang.pertanian.go.id/index. php?option=com_content\&view=article\&id $=1197 \&$ Itemid $=10 \quad$ (diakses tanggal 22 Januari 2015).

Bangun, DA. 2009. Skripsi. Kajian Beberapa Metode Perangkap Lalat Buah (Diptera; Tephritidae) pada Pertanaman Jeruk Manis (Citrus spp.) di Desa Sukanalu Kabupaten Karo.

Boror, JB, CA Triplehorn, and NF Johnson. 2001. Pengenalan Pelajaran Serangga Edisi Keenam. Yogyakarta: Universitas Gadjah Mada University Press: hlm 694. Diterjemahkan oleh S. Partosoedjono.

Cornelius, ML, JJ Duan and RH Messing. 2000. Volatile Host Fruit Odors as Attractants for the Oriental Fruit Fly (Diptera:
Tephritidae). Journal of Economic Entomology 93 (1): 93-100.

Direktorat Perlindungan Hortikultura. 2002. Lalat Buah (Bactrocera spp). Direktorat Perlindungan Hortikultura. Jakarta Selatan

Drew, RAI and DL Hancock. 1994. The Bactrocera dorsalis Complex of Fruit Flies (Diptera: Tephritidae: Dacinae) in Asia. Bulletin of Entomological. Research., Supplement 2. $68 p$

Dumalang, S dan M Lengkong. 2011. Perilaku kawin, uji respon dan identifikasi spesies lalat buah pada belimbing, ketapang, dan paria. Eugenia 17 (3): 192-201.

Epsky, DN and RR Heath. 1998. Exploiting the interactions of chemical and visual cues in behavioral control measures for pest tephritid fruit flies. Florida Entomologist. 81 (3): 273-282.

Fein, BL, WH Reissig, and WL Roelofs. 1982. Identification of apple volatiles attractive to the apple maggot, Rhagoletis pomonella. J. Chem. Ecol. 8: 1473-1487. Tersedia di http://link.springer.com/article/10.1007\%2F BF00989104 (diakses tanggal 4 Juli 2015)

Hasyim, A, M Muryati, and WJ de Kogel. 2008. Population fluctuation of adult males of the fruit fly, Bactrocera tau Walker (diptera: tephritidae) in passion fruit orchard in relation to abiotic factors and sanitation. Indonesian Journal of Agricultural Sciences 9 (1): 29-33.

Hasyim, A, A Boy, dan Y Hilman. 2010. Respons hama lalat buah jantan terhadap beberapa jenis atraktan dan warna perangkap di kebun petani. J. Hort. 20 (2): 164-170.

Heriza, S, T Himawan dan H Tarno. 2013. Penggunaan tongkol jagung dan pepaya sebagai bahan dasar pakan buatan bagi perkembangan larva lalat buah Bactrocera carambolae Drew dan Hancock (Diptera: Tephritidae). Jurnal HPT 1 (1): 80-89.

Himawan, T, P Wijayanto dan S Karindah. 2013. Pengaruh beberapa aroma buah terhadap preferensi oviposisi Bactrocera carambolae Drew dan Hancock (Diptera: Tephritidae). Jurnal HPT 1 (2): 72-79.

Jang, EB, and DM Light. 1996. Olfactory semiochemicalsof tephritids, pp. 73-90. In B. McPheronand G. Steck [eds.], Fruit Flies Pests: A worldassessment of their biology and management. Proceedingof the Fourth International Symposium on Fruit Flies of 
Economic Importance, Sand Key Florida. 586 pp. St. Lucie Press. Delray Beach FL.

Kardinan, A. 2003. Mengenal Lebih Dekat Tanaman Pengendali Lalat Buah. Bogor. Agromedia Pustaka. $49 \mathrm{hlm}$.

Lengkong, M, CS Rante dan M Meray. 2011. Aplikasi MAT dalam pengendalian lalat buah Bactrocera sp. (Diptera :Tephritidae) pada tanaman cabe. Eugenia 17 (2): 121127.

Manurung, B, P Prastowo, dan EE Tarigan. 2012. Pola aktivitas harian dan dinamika populasi lalat buah Bactrocera dorsalis Complex pada pertanaman jeruk di dataran tinggi Kabupaten Karo Provinsi Sumatera Utara. Jurnal HPTTropika, 12(2): 103-110

Nasution, IA dan AN Kuswadi. 2012. Sterilitas Lalat Buah Bactrocera papayae dengan Mengunakan Iradiasi Gamma dalam Pengendalian dengan Teknik Serangga Mandul (TSM). Prosiding Simposium dan Pameran Teknologi Aplikasi Isotop dan Radiasi.

Novriarche, G. 2012. Identifikasi Lalat Buah (Diptera: Tephritidae) pada (Mangifera indica) di Kecamatan Kidul Daerah Istimewa Yogyakarta Lalat Buah (Diptera: Tephritidae) pada Mangga Kecamatan Gedangsari Kabupaten Gunung Daerah Istimewa Yogyakarta Angga Malam Gunung. S1 Thesis, Universitas Negeri Yogyakarta.

Peraturan Menteri Pertanian. 2005. Persyaratan Teknik dan Tindakan Karantina Tumbuhan untuk Pemasukan Buah-Buahan dan Sayuran Buah Segar ke dalam Wilayah Negara Republik Indonesia.

Prokopy, RJ and BD Roitberg. 1984. Foraging behavior of true fruit flies: concepts of foraging can be used to determine how tephritids search for food, mates, and egglaying sites and to help control these pests. American Scientist 72 (1): 41-49.

Prokopy, RJ, RAI Drew, BNE Sabine, AC Lloyd, and E Hamacek. 1991. Effect of physiological and experiential state of Bactrocera tryoni flies on intra-tree foraging behavior for food (bacteria) and host fruit. Oecologia 87 (3): 394-400.

Raghu, S and AR Clarke. 2003. Spatial and temporal partitioning of behaviour by adult dacines: direct evidence for methyl eugenol as a mate rendezvous cue for Bactrocera cacuminata. Physiological Entomology 28 (3): 175-184.

Robacker, DC and I Fraser. 2005. What do Mexican fruit flies learn when they experience fruit?. Journal of Insect Behavior 18 (4) : 529-542.

Sati, AMK. 2003. Population Dynamics and Movement of Bactrocera umbrosa (Fabricius) in Relation To B. papayae (Drew \& Hancock) (Diptera: Tephritidae) In Penang Island, West Malaysia. Thesis. Tersedia di http://eprints.usm.my/6316/1/POPULATIO N_DYNAMICS_AND_MOVEMENT_OF_B actrocera_umbrosa_\%28FABRICIUS\%29_I N_RELATION_TO_B._papayae_\%28DRE W_\%26_HANCOCK\%29_\%28DIPTERA_T EPHRITIDAE\%29_IN_PENANG_ISLAND, _WEST_MALAYSIA.pdf (diakses tanggal 20 Januari 2015).

Sauers-Muller, van A. 2005. Host plants of the carmbola fruit fly, Bactrocera carambolae, in Suriname, South America. Neotrapical Entomology 34 (2): 203-214.

Shelly, TE. 2010. Effects of methyl eugenol and raspberry ketone/cue lure on the sexual behavior of Bactrocera species (Diptera: Tephritidae). Appl. Entomol. Zool. 45 (3): 349-361.

Siwi, SS, P Hidayat, dan Suputa, 2006. Taksonomi dan Bioekologi Lalat BuahPenting, Bactrocera spp. (Diptera : Tephritidae) di Indonesia. Balai Besar Penelitian dan Pengembangan Bioteknologi dan Sumberdaya Genetik Pertanian. Bogor. 65 hlm.

Sunarno. 2011. Ketertarikan serangga hama lalat buah terhadap berbagai papan perangkap berwarna sebagai salah satu teknik pengendalian. Jurnal Agroforestri 4 (2): 129-134.

Susanto, A. 2010. Estimasi dan Dinamika Populasi Lalat Buah, Bactrocera dorsalis Kompleks (Diptera: Tephritidae) Pada Pertanaman Mangga. Disertasi Program Pasca Sarjana. Institut Teknologi Bandung, Tidak dipublikasi. $105 \mathrm{hlm}$.

Szentesi, A, PD Greany and DL Chambers. 2011. Oviposition behavior of laboratory-reared and wild Caribbean fruit flies Anastrepha suspensa (Diptera: Tephritidae): I. selected chemical influences. Entomologia 
Experimentalis et Applicata 26 (3) : 227238.

Vargas, RI, RJ Prokopy, JJ Duan, C Albrecht and QX Li. 1997. Captures of wild Mediterranean and Oriental fruit flies (Diptera: Tephritidae) in Jackson and Mcphail traps baited with coffee juice. Journal of Economic Entomology 90 (1) : 165-169.

Wati, R, R Sumarmin dan M Wati. 2013. Pengaruh kombinasi petrogenol dan ekstrak belimbing (Averrhoa carambola L.) terhadap perilaku makan lalat buah (Bactrocera dorsalis Hend.). Skripsi. Biologi PMIPA. Padang: STKIP PGRI Padang.

Zhang, A, C Linn Jr, S Wright, R Prokopy, W Reissig and W Roelofs. 1999. Identification of a new blend of apple volatiles attractive to the apple maggot, Rhagoletis pomonella. Journal of Chemical Ecology 25 (6): 1221-1232. 